\title{
Sundanese Qur'anic Commentaries and Its Contributions on Preserving Sundanese Language in West Java
}

\author{
Dadang Darmawan \\ Faculty of Ushuluddin, \\ UIN Sunan Gunung Djati \\ Bandung, Indonesia \\ Syarif Hidayatullah State Islamic \\ University Jakarta, Indonesia \\ dadang.darmawaneuinsgd.ac.id
}

\author{
Izzah Faizah Siti Rusydati Khaerani \\ Faculty of Ushuluddin \\ UIN Sunan Gunung Djati \\ Bandung, Indonesia \\ Syarif Hidayatullah State Islamic \\ University Jakarta, Indonesia \\ izzahfaizahsiti@uinsgd.ac.id
}

\author{
Irma Riyani \\ Faculty of Ushuluddin. \\ UIN Sunan Gunung Djati \\ Bandung, Indonesia \\ Syarif Hidayatullah State Islamic \\ University Jakarta, Indonesia \\ Irmariyani@uinsgd.ac.id
}

\begin{abstract}
Endangerment of local language becomes an issue of discussion among many linguists all over the world. In fact, language serves as an identity of a nation. Thus, any attempts to preserve local language become the important thing to do. There are many strategies to preserve the existence of local language and one of them is through literacy. This study attempts to investigate the contribution of Sundanese exegesis (tafsir Sunda) in preserving and maintaining the vitality of Sundanese language. This study uses qualitative method with two components: textual study and fieldwork. This research shows the role of tafsir Sunda in preserving Sundanese language in several aspects namely: the contribution of text material transmitted in several pesantren, especially traditional pesantren, that use Sundanese as a language of instruction in its teaching; the contribution of model of transmission that use regularly and continuously; and it to be transformed into a digital mode to ease young generations accessing it. Pesantren, pengajian and majlis ta'lim are considered places to practice Sundanese language in teaching and learning process of tafsir Sunda. These factors can be the effective tools to sustain and preserve Sundanese language from the extinctions.
\end{abstract}

Keywords —exegesis; preserve; Sundanese; sustain; tafsir; transmit.

\section{I.INTRODUCTION}

Sundanese is one of the best languages in the world. It becomes the popular language from 706 local languages in Indonesia. Furthermore, Cohn [1] and Tondo [2] state that Sundanese is being the second largest spoken language that used in Indonesia after Javanese language. For about 33 million people speak Sundanese every day [3], [4]. However, at the same time, Sundanese is endangered because people, especially younger generation, avoid speaking Sundanese and prefer to speak Indonesian instead. A research by Ravindranath and Cohn [1] shows that the establishment of Indonesian as nation language threatened the usage of indigenous Indonesian language including Sundanese. The situation is getting worse by the process of cultural urbanization and acculturation which has lessened the loyalty of Sundanese people to use their language in everyday communication. A number of
Sundanese children who avoid speaking Sundanese in their daily interaction either at school or at home are increased steadily particularly in some urban areas [3]. This has result in endangering the vitality of Sundanese language that could lead to extinction [4]. Thus, any attempts of preserving Sundanese language as part and identity of 33 million Sundanese ethnic from extinction is necessary and should be supported.

One of important channels that is effective to sustain Sundanese language is through religion (Islam). Islam as identical with Sundanese ethnic is an important aspect in sustaining Sundanese language. According to Ekadjati (2010) almost 95\%, or according to Kahmad (2005) $98 \%$ Sundanese people adhered to Islam as their religion. Islamic teachings that taught in Islamic centers like madrasah (Islamic schools), majlis ta'lim (religious study gathering) and pesantren (Islamic boarding schools) use Sundanese language as a language of instruction of teaching and learning process. These Islamic centers of teaching and learning are places that support sustaining Sundanese language. Among several Islamic teaching materials utilized Sundanese language which distributed and learned among students in pesantren and majlis ta'lim is Qur'anic tafsir written in Sundanese language. Although the availability of tafsir Sunda is limited if it is compared to the literature of Islamic laws pertaining to ritual obligation [5], tafsir Sunda remain the main reference used and taught in pesantren and majlis ta'lim until now. Al-Qur'an as the primary source of Islam is the most recited and learned by Muslim all over the word and the demand to its interpretation is increasing speedy.

\section{METHOD}

This study uses qualitative methodology that involves two main components: textual study and fieldwork. For fieldwork, two data collection methods are adopted namely: in depth interview and observation. In-depth and open-ended interviews are used to uncover "people's views of reality" $[6$, p.18] during fieldwork. Through interviews, the 
researcher has an opportunity to acquire "people's ideas, thoughts, and memories" [6, p.19], allowing research participants to express things in their own words, and to elaborate on those topics that are of most interest to them. Fieldwork is conducted with pesantren leaders in West Java and preachers of majlis ta'lim in Bandung. In terms of textual study, tafsir Sunda is analysed by using content analysis.

\section{RESULT AND DISCUSSION}

UNESCO released six factors as the indicator to the survival of local languages, namely: (1) Intergenerational Language Transmission; 2) Absolute Number of Speakers ; 3) Proportion of Speakers within the Total Population; 4) Trends in Existing Language Domains; 5) Response to New Domains and Media; and 6) Materials for Language Education and Literacy [4]. Using the indicators above, tafsir Sunda included in number six that is provide material in education and literacy.

Reported that there are about 27 Qur'anic tafsir written in Sundanese languages [5]. These tafsir Sunda were written in various periods from pre independence periods to post independence. Several of them include: Qur'anul Adhimi written by Haji Hasan Mustapa (1921), Al-Qur'an Sundawiyah by Muhammad Kurdi (1927), Tafsir AlFurqan translated into Sundanese by Djoeragan $\mathrm{Mh}$. Anwar Sanusi \& Djoeragan Mh. Djoenaedi (1929). Other tafsir were written by Kyai H. Ahmad Sanoesi (18881850), Pengajaran Dengan Bahasa Sunda atau Malja' alTālibìn fì Tafsìr Kalām Rabb al- 'Alamīn, Kasyf al-Auhām wa al-Dzunūn fì Bayān Qaulih Ta'ālà lā yamassuh illāa alMuthahharūn, Raudat al-'Irfān fì Ma'rifat al-Qur'ān, Hidāyat al-Qulūb fì Fajl Sūrat; Tafsir Surah Al-Baqarah by R.A.A Wiranatakoesoemah and R.A.A Soeriamihardja (1949), Tafsir Hibarna (Juz Amma) by Kol. Isa Idris (1951), Qoer'an Tarjamah Soenda 3 volumes by Adjengan H. Mhd Romli, Nurul Bajan; Tafsir Qur'an Basa Sunda, 3 volumes by H. Mhd. Romli and H. N. S Midjaja (1960), Tarjamah Juz 'Amma Basa Sunda karya K.H. Qamarudin Shaleh (1965), Al-Amin; Al-Qur'an tarjamah Sunda by K.H. Qamaruddin Shaleh and Yus Rusmani (1971), Al-Kitab al-Mubin: Tafsir basa Sunda, 2 volumes by K.H. Mhd. Romli (1974), Tarjamah Al-Qur'an Bahasa Sunda 3 volumes, by the tim of Religious Ministry of West Java (1974), Terjemah dan Tafsir Al-Qur'an Bahasa Sunda, by the tim of Religious Ministry of West Java (1978), Tafsir Al-Qur'an Basa Sunda six volumes, by the tim of Religious Ministry of West Java (1981), Ayat Suci Lenyepaneun by E. Hasim (1981), Tafsir Rahmat Basa Sunda translated by H. M Sulaiman by H. Oemar Bakri (1986), Tarjamah Tafsir Al-Qur'an Al-Adim Li Jalaluddin as-Suyuthi wa Jalaluddin Al-Mahalli, 6 volumes by K.H. Makki (1989), Nur Hidayah: Saritilawah basa Sunda, AlQur'an 30 Juz Winangan Pupuh (1980-1998), Nadoman Nurul Hikmah Al-Qur'an 30 Juz (2001) by H. R. Hidayat Suryalaga, Qomus Al-Qur'an Basa Sunda 30 Juz by Anwar Huda (1995), Kitab Suci Al-Qur'an Tarjamah Sunda, 3 volumes translated by the commetee of Qur'anic translation of Ahmadiyah in Indonesia (1998), Al-Qur'an Mushaf Sundawi, by the tim of Religious Ministry of West Java (2000), Al- Qur'an Miwah Tarjamahna Dina Basa Sunda, by the tim of Religious Ministry of West Java (2002), AlMunir; Al-Qur'an Tarjamah Basa Sunda, by M. Djawad Dahlan, Al-Huda; Al- Qur'an Tarjamah ku Basa Sunda 30 $J u z$ translated by Kyai Miftahur Rahman, Sa'adat AdDarayn fi Tarjamah at-Tafsir Al-Qur'an al-'Adim li Jalaluddin as-Suyuthi wa Jalaluddin Al- Mahalli by Muhammad Abdullah bin Al-Hasan Caringin Sukabumi (2000), Al-Hikmah Tarjamah Al-Qur'an Basa Sunda Juz Ka-1, by Mariyah Maryati Sastrawijaya (2009), tafsir AlRazi, Tafsir juz Amma Basa Sunda by UU Suhendar (2011) [5].

This research indicated several contributions of tafsir Sunda in preserving the existence of Sundanese language through its text material, mode of transmission and strategy for future challenge. Each of these contributions will be explain in detail as follow.

\section{- Sundanese Qur'anic Tafsir and its Contribution in Preserving Sundanese Language}

Most of tafsir Sunda stated above are stored in museum or in private collection and hardly read by ordinary people. However, these interpretations have given significant contribution in enriching Sundanese literatures that functioned as restoring Sundanese words and classical Sundanese weltanschauung. Many Sundanese words are no longer recognized due to rare usage in daily communication. Tafsir Sunda recorded many classical Sundanese words, idioms, philosophy, norms, poets, and advices and many important teachings. Thus, the contribution of tafsir Sunda is unquestioned in preserving Sundanese language from extinction. In tafsir Sunda, the Sundanese norms and values are integrated along with Islamic lessons derived from every verse and chapter in the Qur'an. Furthermore, Tafsir Sunda served as references that capture the development of Sundanese words through times. Tafsir Sunda restored and preserved Sundanese language that no longer used in contemporary interaction and communication.

Initially, the usage of Sundanese in Qur'anic interpretation aimed at giving easiness in delivering the messages and explanation of Qur'anic lessons to Sundanese community. Therefore, these lessons can be easily absorbed and implemented in daily life because of its resemblance with Sundanese values [5], [7]. Nowadays, these tafsir can be recognized as one of assets in preserving local language. Similarly, the Qur'an has preserved Arabic language for over 1400 years, so did tafsir Sunda for as long as tafsir Sunda is maintained.

- Sundanese Qur'anic Tafsir and its Contribution in Vitality of Sundanese Language

Tafsir Sunda served not only preserved Sundanese language but also strengthened its existence. According to 
the UNESCO report, some factors related to the vitality of local language include: (1) the availability of texts of such language; (2) The usage of such language in education; (3) the usage of the language for governmental administration; and (4) The usage of the language in media and publication which produced regularly. Tafsir Sunda fit perfectly with the first and second category which have already mentioned above as the factors of language vitality stated by UNESCO. Tafsir Sunda provides texts in Sundanese language to be read and learned repeatedly and continuously in several Islamic centers like madrasah, majlis ta'lim and pesantren.

TABLE I

INDICATORS OF LANGUAGE VITALITY ACCORDING TO UNESCO Source: Language Vitality and Endangerment International Expert Meeting on UNESCO Programs Safeguarding of Endangered Languages Paris, 10-12 March 2003

\begin{tabular}{|c|l|}
\hline Grade & \multicolumn{1}{|c|}{ Accessibility of Written Materials } \\
\hline 5 & $\begin{array}{l}\text { There is an established orthography, literacy } \\
\text { tradition with grammars, dictionaries, texts, } \\
\text { literature, and everyday media. Writing in the } \\
\text { language is used in administration and } \\
\text { education. }\end{array}$ \\
\hline 4 & $\begin{array}{l}\text { Written materials exist, and at school, } \\
\text { children are developing literacy in the } \\
\text { language. Writing in the language is not used } \\
\text { in administration. }\end{array}$ \\
\hline 3 & $\begin{array}{l}\text { Written materials exist and children may be } \\
\text { exposed to the written form at school. } \\
\text { Literacy is not promoted through print media. }\end{array}$ \\
\hline 2 & $\begin{array}{l}\text { Written materials exist, but they may only be } \\
\text { useful for some members of the community; } \\
\text { and for others, they may have a symbolic } \\
\text { significance. Literacy education in the } \\
\text { language is not a part of the school } \\
\text { curriculum. }\end{array}$ \\
\hline $\begin{array}{l}\text { A practical orthography is known to the } \\
\text { community and some material is being } \\
\text { written. }\end{array}$ \\
\hline $\begin{array}{l}\text { No orthography available to the community. } \\
\text { ang }\end{array}$ \\
\hline 5
\end{tabular}

Among 27 tafsir Sunda available on hands, some of them are regularly used in Sundanese Muslim community. Two of them among the prominent of tafsir Sunda, are Raudat al- 'Irfān fì Ma'rifat al-Qur'ān by kyai haji Ahmad Sanoesi dan Ayat Suci Lenyepaneun by E. Hasim. These two tafsir are sustained among Sundanese society because they are regularly read and taught among them. The former is well-known in rural community while the latter is popular among urban community.
Raudat al- 'Irfān among others is the most popular tafsir in Sundanese community. According to one report, it has been published more than 50,000 copies and is still being learned until recently in pesantren in West Java [8]. Although, there are pesantren in West Java that taught tafsir written by Middle Eastern scholars like tafsir Jalalayn [9], tafsir Raudat al- 'Irfān fì Ma'rifat al-Qur'ān is popular to be taught in several pesantren in Sukabumi, Cianjur and Cililin, Bandung. In these pesantren, this tafsir provides texts for educational purpose not only to Islamic boarding school students but also to wider community around pesantren through pengajian and majlis ta'lim.

The transmission of tafsir Sunda in rural area contains two recipients. For instances, (1) transmission to the wider community and (2) transmission to spesific audience in educational institution like pesantren. There are differences in teaching models for each recipient. The transmission in educational institution like pesantren to the students conducted by reading each verse in the Qur'an and then the kyai explains the literal meaning of each word using Sundanese language and the students annotate on the side or below of its verse. The main concern of Sundanese interpretation is focusing on the literal meaning which is ascertained by annotating the text word by word; this process is called ngalogat. The mode of transmission to the wider community through pengajian or majlis ta'limis conducted by reading, the audience only read the verse in Arabic and its Sundanese translation which already provided, and there is no need for annotatingactivity.

Tafsir Ayat Suci Lenyepaneun by E. Hasyim is another tafsir Sunda that prominent among Sundanese community. Since its publication in 1982, this tafsir is most read by Muslim in urban area. It contains the meaning of every verse in the Qur'an and its explanation word by word or sentences in details. The language style produced in this tafsir is simple and easy to understand and supplement by illustration of daily life of Sundanese [10, p.1]. This interpretation utilized Sundanese language level (undak usuk/ lancaran) that easier for the reader to understand. Thus, this tafsir has received appreciation from Sastra Rancage in 2001 for its attempt to preserve Sundanese language [7]. Urban community make use this tafsir to find guidance in daily life. This tafsir is suitable for urban lifestyle for refining Sundanes language used in this tafsir. This tafsir also served as educational text used by parents to educate their children. Furthermore, it is usually learned together among family members. The head of the family reads its explanation that encompassed with Sundanese values and norms. Also, it is used for study gatherings in urban society who eager to study and deepen Islamic teaching.

- Sundanese Qur'anic Tafsir and its Contribution in facing the Challenge for its Existence in the Future

The challenge faced to sustain Sundanese language in the future is tough. Many challenges come from globalization and its sophisticated information technology. 
There should be a good strategy in order to preserve Sundanese from its extinction. In this stage, the role of tafsir Sunda is important in sustaining language existence in the future. Attempt is to update and modify its appearance into digital mode. The digitalization of tafsir Sunda will provide an easy access of this literature to younger generation. By accessing this tafsir in digital mode, the reader can study tafsir their hands while learning the Sundanese language at the same time. Thus, it is necessary to transform paper based tafsir into digital to adapt with the changing community in contemporary era.

\section{CONCLUSION}

From the above explanation related to preserving local Sundanese language through tafsir Sunda, several findings of the research will be provided as follow:

Tafsir Sunda is considered important asset in preserving Sundanese language from its extinction. Tafsir Sunda fit very well with the indicators provided by UNESCO in preserving local language. The finding of the research notes several contributions of tafsir Sunda in sustaining the existence of Sundanese language namely: (1) Tafsir Sunda served as preserving Sundanese language through its text materials used for education in teaching and learning process; (2) Tafsir Sunda served as maintaining vitality through models of transmitting routinely, regularly and continuously in several educational institution like pesantren, pengajian and majlis ta'lim; (3) Tafsir Sunda functioned to face challenge for the future through the transformation into digital mode to reach wider reader in information technology era. Those three contributions have result in tafsir Sunda as important factors in preserving Sundanese language and avoid the extinction of Sundanese interpretation in the future.

\section{REFERENCES}

[1] B. Bailey and Sunny Lie, "The Politics of Names among Chinese Indonesians in Java.)," J. Linguist. Anthropol., vol. 23, no. 1, pp. 21-40, 2013.

[2] M. N. Huda, "Ini Gelar Sultan HB X Sesuai Sabdaraja dan Penjelasannya," Tribun Jogja, Jogja, Mei 23:03-2015.

[3] J. Hoesterey, Rebranding Islam: Piety, Prosperity, and a Self-Help Guru. Stanford: Stanford University Press, 2015.

[4] J. C. Kuipers and Askuri, "Islamization and Identity in Indonesia: The Case of Arabic Names in Java," Indonesia, vol. 103, 2017.

[5] Djatmika, "Pemberian Nama Panggilian dalam Masyarakat Jawa".," 2011.

[6] R. Hendrawanto, "Antara Islam dan Budaya Arab," Kompasiana, Desember 2014.

[7] de Grave and Jean-Marc, "Naming as a Dynamic Process," Indoneia. Malay World, vol. 39, no. 113, pp. 69-88, 2011.

[8] Rusman and Evi Mariani, "Long Difficult Names for Kids is the New Trend in Indonesia," Jkt. Post, Sep. 2014. 